\title{
Avaliação Microbiológica e Sensorial de Suco Misto com Característica Cítrica
}

\author{
Mônica Turchetto (I), Endy Camile de Noronha (I), Gilson Parussolo \\ (I), Rafael Porto Ineu (I) \\ (I) UFSM - Universidade Federal de Santa Maria (Linha Sete de Setembro, s/n, CEP: 98400- \\ 000, Frederico Westphalen, RS, Brasil)
}

\section{Resumo}

Nas grandes produções agrícolas, existe um excedente da safra de frutas que não é comercializado in natura, podendo chegar a $30 \%$ da produção. Assim, uma alternativa para o aproveitamento deste excedente, é empregálo como matéria-prima no processamento de derivados, agregando valor ao produto e incrementando a renda dos fruticultores. O consumo de sucos das frutas in natura tem aumentado motivado pela necessidade crescente da população em ingerir alimentos saudáveis e também devido as característica sensoriais. Com isso, a utilização de frutas cítricas na elaboração de sucos, contribui para o aproveitamento do excedente de produção e fornece um produto com características sensoriais e nutricionais agradáveis. Sendo assim, o objetivo do presente trabalho foi testar diferentes formulações de suco misto cítrico, avaliar sua estabilidade microbiológica, bem como verificar sua aceitabilidade e intenção de compra perante os consumidores. Foram elaboradas quatro formulações diferentes de sucos mistos, com $60 \%$ polpa e $40 \%$ água: SMA com polpa de laranja, bergamota e maracujá, SMB com polpa de laranja, bergamota e abacaxi, SMC com polpa de bergamota, maracujá e abacaxi e SMD com laranja, maracujá e abacaxi. Realizaram-se análises quanto a coliformes totais e aplicados os testes de aceitabilidade com escala hedônica e atitude de compra. Os resultados obtidos foram submetidos ao Teste de Tukey a $5 \%$ de significância $(\mathrm{p} 0,05)$ entre as amostras com relação à análise microbiológica, mas houve diferença entre as amostras na análise sensorial. 
A utilização das frutas cítricas na elaboração de sucos proporciona produtos microbiologicamente seguros e com características sensoriais agradáveis, com boa aceitabilidade perante os consumidores, constituindo assim uma excelente alternativa de aproveitamento do excedente de produção.

Palavras-Chave: Frutas cítricas, coliformes totais, aceitabilidade Agência de Fomento: 